Isaac Milton Namwanja Kigongo-Bukenya

\title{
Towards Professionalism and Commitment in Africa: the case for theory and practice of Information Ethics in Uganda
}

\begin{abstract}
:
Though one could not exhaustively and conclusively define all the attributes of an information/knowledge society, it seems Uganda has made commandable strides to such society. One of the prerequisites of such society is a corps of well-educated, trained and experienced information professionals to manage information and knowledge effectively in that society. Furthermore, the corps must perform professionally and ethically at all times. To fulfill this, an Information Code of Ethics (ICE) is required. However, Uganda has as yet to establish an ICE because of some reasons. These reasons are outlined in the paper. The ICE has two aspects: theory and practice. These concepts are explained and related. The LA (USA) and the Chartered Institute of Library and Information Professions (CILIP) formerly the LA (UK) are studied as living examples. The provisions of these ICEs are briefly explained. In view of the past experience a process of establishing an IME for Uganda is considered. The paper concludes with an outline of the content of an IME for Uganda.
\end{abstract}

\section{Agenda}

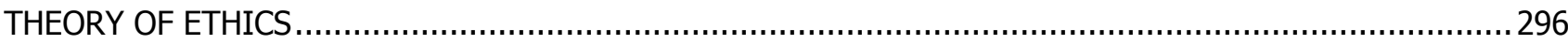

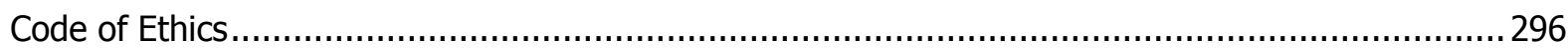

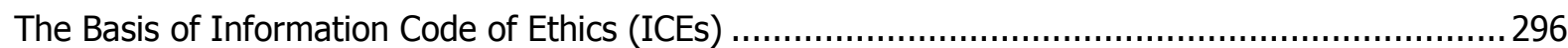

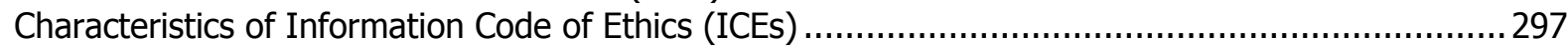

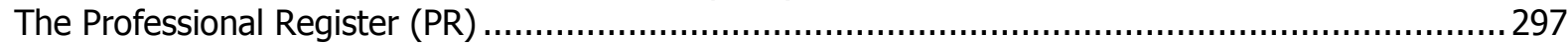

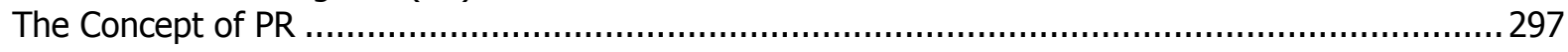

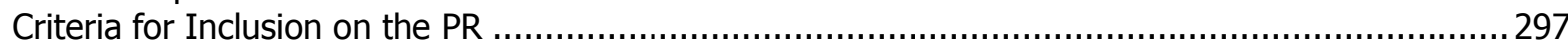

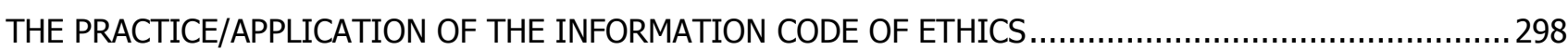

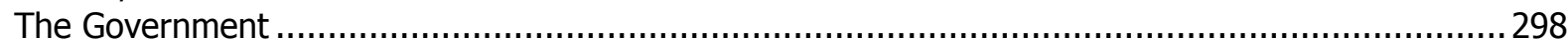

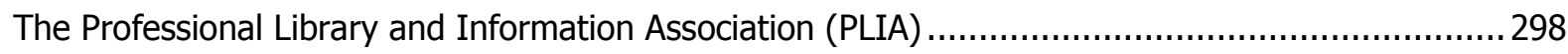

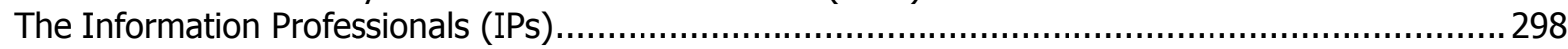

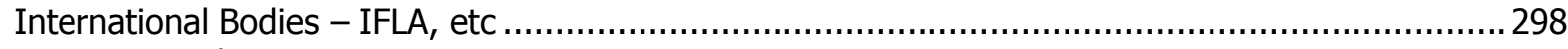

ICE in UK and USA

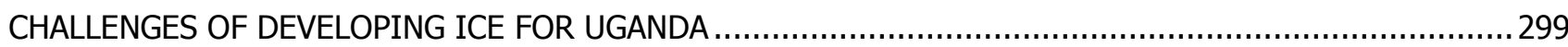

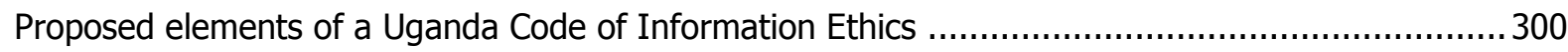

SUMMARRISED PROPOSED CODE OF ETHICS FOR THE INFORMATION PROFESSION IN UGANDA .............300

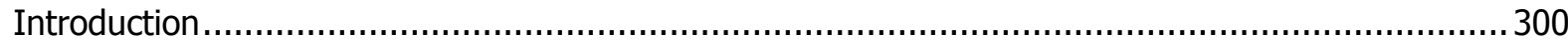

\section{Author:}

Prof. I.M.N. Kigongo-Bukenya:

- East African School of Library and Information Science Makerere University, P.O. Box 7062, Kampala, Uganda

- $\widetilde{\mathbb{2}}+256752$ 699266, $ه$ kigongo bukenya@hotmail.com 
The era of the information society has tightened its grips on Uganda. The Uganda Parliament has enacted several laws related to library and information services, a reflection of commitment to information, the key to the development of its citizens. Ugandans crave for information either as business venture or raw resource for development. Many information professionals are employed by organisations and institutions throughout Uganda thereby through taxation contributing to Uganda GDP. The above are indicators of an information society (IS)/knowledge society (KS).

One of the engines of an IS/KS, are a corps of well educated and trained information professionals to execute information related responsibility according to moral set standards. This is the concern of theory and practice of ethics enshrined in an information code of ethics.

\section{THEORY OF ETHICS}

Theory in this paper refers to the documented literature on the concept, philosophy, mechanisms, principles, regulations and evaluation of Information Code of Ethics (ICE). Such literature is consumed to guide and inform the managers and practioners as well as students, researchers, library and information clients on issues of the information code of ethics. Some of this informing literature is reviewed in the following paragraphs.

\section{Code of Ethics}

Ethics comes from a Greek word Ethos (custom) and "has to do with conduct, theory of what is ultimately good or worthwhile, of good conduct and character, or moral rights obligations" (Boaz 1972) ${ }^{1}$. Ethics are the customs or standards which a particular group or community acts on (Donalson 1990) ${ }^{2}$. Information professionals should have basic understanding of ethical behaviour by its members, such as conducting oneself in the highest moral standards, ensuring organizational compliance with the spirit as well as letter of pertinent laws and regulations, and reporting to appropriate internal or exter-

1 Boaz, Martha (1972): "Code of Ethics, Professional". In: Encyclopedia of Library and Information Science. Pg 245-252.

2 Donalson, J. (19900): Key Issues in Business Ethics, London: The Academy Press nal authority any illegal or fraudulent act by the organisation. The ICE or Code of Conduct(CC) gives guidelines to professional conduct and provide guidelines in the ethical decision making process. (Jefferson and Contreras, 2005) ${ }^{3}$. An ICE also establishes high standards against which individuals can measure their own performance and communicate to those outside the organisation the value system from which the organisation members must not be asked to deviate (Vanasco 1994) ${ }^{4}$. Iacovino $(2002)^{5}$ rightly concludes that ethical principles enable us to reach normative judgments, guide our thinking by providing us with the basis for determining how we should act when ethical issues arise. They do not provide definite answers; only answers that can be justified by way of argument depending on the ethical view points adopted, and the decision making models and process employed.

\section{The Basis of Information Code of Ethics (ICEs)}

Kigongo-Bukenya has outlined the basis for ICEs as follows:

- Golden Rule, which must either, be stated or implied: loyalty, honesty, generosity, courtesy, frankness, goodwill, cooperation, friendliness, charity and sincerelity - which are general standards or ideals of conduct.

- Voluntary Spirit: Most codes are voluntary because they are products of professionals' volition and therefore the extent of its efficiency depends upon mutual understanding and common interest.

- Machinery: each code should establish controlling machinery; and an arm in the form of disciplinary committee to correct deviations.

3 Jefferson, Rene'e N.; Contreras, Sylvia 2005. Ethical perspectives of library and information science graduate students in the United States. New Library World 106 (1208/1209): 58-66.

${ }^{4}$ Vanasco, Rocco R. (1994): The IIA Code of Ethics: An International Perspective. Managerial Auditing Journal. 9(1): 12-22.

${ }^{5}$ Lacovino. L. (2002): "Ethical principles and information professionals: Theory, practice and education" Australian Academic and Research Libraries, Vol. 33 No. 2, pp. 57-74. 


\section{Characteristics of Information Code of Ethics (ICEs)}

Any ICE should incorporate the following (KigongoBukenya, 1995) ${ }^{6}$ :

1. Duty to Client and Employer: This refers to the guiding principle that priority should be paid to the interests of the clients within prescribed or legitimate requirements. The professional must be loyal and obedient to the employers within legitimate requirements.

2. Updating Professional Expertise: Members must be competent in their activities including the requirement to keep abreast of development and those branches of professional practice in which qualifications and experience entitle them to engage.

3. Supervision of Staff and Trainees: Experienced professionals must provide supervision and training to the juniors to ensure steady professional development leading to independent responsibility.

4. Non discrimination on race, colour, creed, gender and sexual orientation: Professionals should not exercise discrimination based on race, colour, gender or sexual orientation in the execution of their services to clients except as limited by legal practice.

5. Confidentiality: Professionals should not divulge information gathered during the course of execution of duties to their clients. Clients are entitled to secrecy of what transpires between them and the professionals. However, professionals are absolved from the "confidentiality-tenet" in so far as required by law or in answering questions under the disciplinary committee.

6. Personal Financial Interest: Members' actions and decisions should be determined solely by their professional judgment and they should not profit from their positions other than by normal remuneration or fee for professionals services. Under no circumstances should a query remain unanswered.

${ }^{6}$ Kigongo-Bukenya, I M N.(1995): The Case for a Register and a Code of Ethics for Information Professionals in Uganda. The Chairman's Professional Address on the Occasion of Uganda Library Association Dinner, Uganda Libraries, Vol. 2 No. 2, p. 3-7.
7. Criminal Offence: Members must report the facts to the secretary of the Professional Association if convicted of any offence involving disciplinary or one, which brings the profession in disrepute.

8. Cooperation in Disciplinary Proceedings:

- Professionals must respond to any requirements from the disciplinary committee for comments or information on a complaint;

- Attend the committee proceedings when required to do so;

- Attend upon a nominated person for the purposes of receiving guidance as to future conduct if required to do so.

\section{The Professional Register (PR)}

A (PR) is a list of eligible professionals accepted by authority to practice in the profession. An independent body set up by law administers the PR. Such authority performs the following functions:

1. Exercises general supervision and control over professional education

2. Advises and makes recommendations to government on the matters of the profession

3. Exercises through the Disciplinary Committee control over professional matters

\section{The Concept of PR}

Professionals provide very important services which would mean life or death to the clients. Consequently stringent measures must be taken to ensure that enrolment is only done after proper education and training, subscribing to the code of ethics, constant inspection, and in case of malpractices facing disciplinary measures. This is a safety measure against impostors who if were allowed to practice would misinform the clients and tarnish the good name of the profession.

\section{Criteria for Inclusion on the PR}

The procedure for enrolment a practicing professional might differ from profession to profession. However the following requirements are similar.

1. Having successfully completed a professional programme of study 
2. Having been supervised by a qualified senior professional in the field to get experience (Internship)

3. Being a citizen of the country (Non-citizens may have other conditions to meet before registration)

4. Fulfilling specialisation

5. Legal and Medical professions demand inspection of facilities and equipment of the chambers, clinics or hospitals to ensure minimum standards and security to clients.

\section{THE PRACTICE/APPLICATION OF THE INFORMATION CODE OF ETHICS}

Practice concerns the management of the process of applying the policies, mechanisms, regulations relating to the ICE. The theory, part of which has been reviewed above, is the knowledge base that drives the implementation. The role of partners in the processes is briefly discussed below.

\section{The Government}

The government sets pace in the development of the LIS in any country. It enacts legislation to provide the basis of authority, sets up the ornanisational structure, provides funding, specifies staff required and provides inbuilt evaluative machinery. Examples of fast growing library and information services in Africa show the impact of personal commitment of respective heads of government in countries like Ghana, and Tanzania, thanks to Nkrumah and Nyerere. Related to the specifics of the implementation of ICE, the government should pass a law to control the profession through creating a PR and controlling authority through adhering to the ICE.

\section{The Professional Library and Information Association (PLIA)}

The PLIA is the heart and brain of the profession. It should unite all the information science professions through a common forum to resolve issues concerning the profession. It must play the role of positive agitation to create awareness and support among the citizens and government. One of the key responsibilities of the PLIA is to ensure accreditation of education and training institutions to produce quality professionals. Furthermore, the PLIA must create active and supportive member institutions and individuals and should conceive and implement the PR and ICE to ensure that only registered people participate in its professional activities and that such professionals perform ethically.

\section{The Information Professionals (IPs)}

These are the individual IPs who shoulder the responsibility of planning, implementation and evaluation of plans in the field. Their education, training, experience, commitment and entrepreneurship will ensure the development of the profession and institutions in the field. It is from them the leaders of the profession emerge.

\section{International Bodies - IFLA, etc}

National professional associations must work hand in hand with international associations in their field particularly IFLA. This is a World Professional body which is the umbrella of information professionals and institutions. IFLA organises annual forum to discuss and resolve issues related to the information fields. IFLA co-operates with institutions such as ISO, FID, ICA, etc, unique to the information professions with which mutual issues are decided and implemented.

\section{ICE in UK and USA}

The Chartered Institute of Library and Information professionals (CILIP) founded in 2003, formerly the Library Association (UK), and the American Library Association (USA) are cases of references in establishing ICE. It should be noted that despite that the LA and ALA were established in 1876 and 1877 respectively, operationalising ICEs never got approved by LA Council till 1983 (subsequently revised in 2005) and by the Council of the ALA in 1995. The reasons for this delay (107 and 118 years) surely indicate the toughness of concluding an ICE. What is striking are the similar provisions of these codes. The ALA ICE for instance affirms its contract with the American people to ensure:

1. Providing the highest level of service to all library users through appropriate and usefully organized resources; equitable service policies; equitable access; and accurate, unbiased, and courteous responses to all requests.

2. Upholding the principles of intellectual freedom and resisting all efforts to censor library resources. 
3. Protecting each library user right to privacy and confidentiality with respect to information sought or received and resources consulted, borrowed, acquired or transmitted.

4. Recognize and respect intellectual property rights.

5. Treating co-workers and other colleagues with respect, fairness and good faith, and advocate conditions of employment that safeguard the rights and welfare of all employees of institutions.

6. Not advancing private interests at the expense of library users, colleagues, or our employing institutions.

7. Distinguishing between personal convictions and professional duties.

8. Striving for excellence in the professional by maintaining and enhancing our own knowledge and skills, by encouraging the professional development of co-workers, and by fostering the aspirations of potential members of the profession.

Koehler and Pemberton (2000) state that the information codes of ethics in USA are prescriptive and aspirational in nature.

Koehler (2001) further clarifies: "the prescriptive, aspiration nature of codes of ethics is in part a function of the society in which these associations are found and in part a function of the role of the professional organisations have been ascribed and ascribe to in the society."

The UK ICE makes similar provision below:

1. Avoiding misconduct in providing information services

2. Members compliance with the Charter and Bye-Laws of the Association

3. Catering for the interest of the clients at all times.

4. Protecting the users right to information

5. Fulfillment of contractual obligations owed to the employer

6. Avoiding any type of discrimination

7. Observe privacy and confidentiality of users

8. Professional judgment

9. Members response to any requirements of the Disciplinary Committee

As Hill (1997) emphatically states, the practical use of the code is: an occasional remider to members especially the new ones that being a member of a profession does entail an obligation to conform to standards of behaviour normal among other members"

\section{CHALLENGES OF DEVELOPING ICE FOR UGANDA}

Thirty four years down the road since the Uganda Library Association was formed after the dissolution of the East African Library Association, no law to control the affairs of ULA, professional register or ICE, have been adopted in Uganda. The reasons are not clear but it is believed that some of the causes are

- Selfishness among the professionals, organisations and institutions. They seem not to like interference in their affairs.

- The government has taken its time to enact enabling legislation partly because of little pressure or negligible political gain that would accrue. For any ICE, there is need for a PR of practicing professionals. Such a register is administered by the designated authority, which should be set up by law. In Uganda, the authority is the Uganda Library Association which is yet to be established by law and see itself establishing a PR. It would be very difficult to even develop and enforce the ICE.

- $\quad$ There are also many people disguising as information professionals. Different disciplines have sprung up and all these are posing as information professionals. Examples include journalists, computer scientists, etc. There is need for a clear identity of who the information professional is and such a person should register with the Association.

- There appear to be lack of .seriousness on the part of ULIA leadership and membership to exert due pressure to put their house in order.

- These efforts are further affected by the nature of the employment sector, which is now becoming more and more privatized. Many organizations employ libraries or information professions without consulting the association.

- $\quad$ Given the socio-economic, political ad cultural conditions of Uganda as a developing country, there is a likely need to censure certain information, like concerning different 
political ideologies, pornography, etc. However, this may conflict with the need to provide for freedom of access to information as may be required under the Code of Ethics.

- But the writing is on the wall. A code of information ethics is long overdue. The Uganda Library and Information Association should wake up and normalize this situation if Uganda were to be counted among the information/knowledge based society, managed by professionals who are controlled by legal authority to ensure quality and professionalism in the field.

\section{Proposed elements of a Uganda Code of Information Ethics}

\section{Unethical behaviours should be avoided. The professional Code of Ethics for Uganda should define unethical behaviour to include all actions that results into unfairness to others, whether those behaviours are legal or not. Examples may include: \\ - Bribery, which is considered to be the most frequently occurring ethical problem interna- tionally (Venasco, Rocco R, 1994); \\ - Accepting personal gifts, because the pro- fessionals' ability to maintain professional objectivity might reasonably be questioned.}

Information professionals should keep themselves up-to-date and continuously develop and grow professionally. When professionals are unaware of current developments standards, they are likely to conduct themselves in an unethical manner.

The Professional Body must render final decisions on disciplinary matters. By taking either of the following actions:

- Censure, involving a written reprimand which outlines the consequences of repeated actions;

- Suspension imposed when the misconduct warrants more serious disciplinary action than a censure; and

- Expulsion of a member or forfeiture of membership for the most serious misconduct cases.

7 Vanasco, Rocco R. 1994. The IIA Code of Ethics: An International Perspective. Managerial Auditing Journal. 9(1): 12-22.
More ethical work environment consists of several steps, which may include:

- The establishment of a code of conduct, an ethics committee, and a policy empowering the professional body to include checking for compliance with the code as part of its responsibility.

- Continuous training on how to deal with ethical dilemmas.

- Willingness to accept responsibility for one's behaviour.

\section{SUMMARRISED PROPOSED CODE OF ETHICS FOR THE INFORMATION PROFESSION IN UGANDA}

\section{Introduction}

A Code of Ethics for Information Professionals must basically address issues related to the standard of conduct, competence, honesty, social implications, professional development and protection of the profession. Therefore below is a proposed Code of Ethics for Uganda's Information Profession.

Information Professionals should act with professional responsibility and integrity in dealing with clients, employers, employees, students and the community generally. By this is meant:

1. Priorities: to serve the interests of clients and employers, employees and students, and the community generally, as matters of no less priority than the interests of my colleagues or than self.

2. Competence: IPs to work competently and diligently for the clients and employers.

3. Honesty: Strive to enhance the quality of life of those affected by IPs work.

4. Social implications: Strive to enhance the quality of life of those affected by IPs work.

5. Professional development: Enhancement IPs development, and that of their colleagues, employees and students.

6. Information profession: To enhance the integrity of the Information Profession and the respect of its members for each other. 
American Library Association, 2004. "Code of Ethics". htt://www.ala.org.aif/ethics.htm/ (Accessed 21 Apr, 2005)

American Library Association 2004, "Libraries: An American Value." http://www.ala.org (Accessed 21 Apr, 2005).

American Library Association, 2004. "Library Bill of Rights." http://ala.org/work/freedom/idr.html (Accessed 21st April, 2005).

Boaz, Martha, 1972. "Code of Ethics, Professional". In: Encyclopedia of Library and Information Science. Pg 245-252.

Donalson, J. 1990. Key Issues in Business Ethics, London: The Academy Press.

Freeman, Mike, 1996. Living by the code: Some issues surrounding a code of conduct for the LIS Profession. New Library World 97(1129):17-21.

Gotterbarn, D. 1992. "The use and abuse of computer ethics", in Bynum, T.W., Maner, W. and Fodor, J.L. (Eds), Teaching Computer Ethics, Research Center on Computing and Society, Southern Connecticut State University, pp. 7383.

Hill, Michael; (1997). Facing up the Dile: conflicting ethics and the modern information professional. FID NewsBulletin 47 (April 1997):107-117.

Koehler, Wallace and Pemberton. Michael. A search for Core Values. Towards a Model Code of Ethics for Information Professionals". Journal of information Ethics 9 (200): 26-54

Lacovino. L. (2002). "Ethical principles and information professionals: Theory, practice and education" Australian Academic and Research Libraries, Vol. 33 No. 2, pp. 57-74.

Jefferson, Rene'e N.; Contreras, Sylvia 2005. Ethical perspectives of library and information science graduate students in the United States. New Library World 106 (1208/1209): 58-66.

Kigongo-Bukenya, I M N. The Case for a Register and a Code of Ethics for Information Professionals in Uganda. The Chairman's Professional Address on the Occasion of Uganda Library Association Dinner, Uganda Libraries, Vol. 2 No. 2, 1995 p. 3-7.

Maddocks, P M (1992) in Vanasco, Rocco R. 1994.

Schweikart, J.A. (1992) in Vanasco, Rocco R. 1994.

Sturges, Paul, 2003. Doing the right thing: Professional ethics for information workers in Britain. New Library World. 104 (1186): 94-102).

The Library Association (UK): Code of Professional Conduct. http://www. ifla.org/faife/ethics/lacode.htm (Accessed on 21 April, 2005).

Vanasco, Rocco R. 1994. The IIA Code of Ethics. An International Perspective. Managerial Auditing Journal. 9(1): 12-22.

Wells, Barron and Spinks, Nelda. 1996. Ethics must be communicated from the top down! Career development international 1(7): 28-30. 